\title{
A New Life for Forest Resources: The Commons as a Driver for Economic Sustainable Development-A Case Study from Galicia
}

\author{
María Bastida ${ }^{1, *(\mathbb{C},}$, Alberto Vaquero García ${ }^{2}$ and Miguel Á. Vázquez Taín ${ }^{3}$ (D) \\ 1 Department of Business Organization and Marketing, Faculty of Economics and Business Sciences, Campus of \\ Santiago de Compostela, University of Santiago de Compostela, 15704 Santiago de Compostela, Spain \\ 2 Department of Applied Economics, Faculty of Business Sciences and Tourism, Campus of Ourense, \\ University of Vigo, 32004 Ourense, Spain; vaquero@uvigo.es \\ 3 Department of Applied Economics, Faculty of Economics and Business Sciences, Campus of Santiago de \\ Compostela, University of Santiago de Compostela, 15704 Santiago de Compostela, Spain; \\ miguel.vazquez.tain@usc.es \\ * Correspondence: maria.bastida@usc.es
}

Citation: Bastida, M.; Vaquero García, A.; Vázquez Taín, M.Á. A New Life for Forest Resources: The Commons as a Driver for Economic Sustainable Development-A Case Study from Galicia. Land 2021, 10, 99. https://doi.org/10.3390/land 10020099

Received: 12 November 2020

Accepted: 19 January 2021

Published: 22 January 2021

Publisher's Note: MDPI stays neutral with regard to jurisdictional claims in published maps and institutional affiliations.

Copyright: (c) 2021 by the authors. Licensee MDPI, Basel, Switzerland. This article is an open access article distributed under the terms and conditions of the Creative Commons Attribution (CC BY) license (https:// creativecommons.org/licenses/by/ $4.0 /)$.

\begin{abstract}
Communal forests are a unique land tenure system and comprise a singular legal category in Galicia. Their persistence over time demonstrates that this community-owned resource has overcome the "tragedy of the commons", showing their capability to successfully develop selfgoverning institutions. However, communal forests have rarely been studied through the lens of economics. This minimizes the opportunity to explore to what extent communities of communal forests might be a driving force of general well-being, citizen empowerment, equity, employment, and local development. In this paper, we focus on this gap and address the opportunities. We detail this special ownership structure that allows residents of rural areas to exploit the forest as if they were a single owner. Moreover, we highlight the potential of communal forests to exploit local resources far beyond extractive processes, enabling the generation of greater added value to the economy while favoring a responsible treatment of resources. This enables productive activity integrated with the rest of the primary sector, while allowing for the maintenance of the population and supporting the local economy. Our results reveal a set of inefficiencies that can jeopardize common forest opportunities to become a sustainable economic activity, such as underqualified management, a low level of interest and commitment among community members, and excessive focus on logging. Thus, we propose several actions to improve collective engagement and active membership to better manage Galicia's forests.
\end{abstract}

Keywords: communal forests; the commons; regional development; the social economy

\section{Introduction}

Europe has a long tradition of common property institutions, which are frequently associated with agriculture and grazing. Despite this deeply rooted experience, socioeconomic changes have threatened the viability of these institutions because they are considered inefficient means of resource management. Consequently, most historical commons have been eliminated in the last two centuries.

Elsewhere, new functions have arisen for commons, so many resources are still managed by community institutions. This applies both to traditional commons (be these renewables or nonrenewable, e.g., forests or irrigation systems) and other common resources that have been built according to eco-social-technical development such as Information and Technology Communications (ITC) Infrastructures, which are referred to as "new commons" and are mainly created through social and learning processes [1-3]. While these changes frequently encompass technical developments, nowadays, social priorities 
lay the foundations for a new generation of uses. In this context, the UN General Assembly adopted the 2030 Agenda for Sustainable Development [4], thus enhancing the need for sustainable growth to contribute to the elimination of poverty through 17 objectives known as the Sustainable Development Goals (SDGs). The SDGs employ a three-fold perspective-economic, social, and environmental-that encourages the emergence of a new economic paradigm based on the balance between sustainable development and economic growth [5].

While most of this agenda is quite generic, some objectives point to a set of resources that have been traditionally managed through the commons. In particular, agriculture and forests play a leading role in SDG2 (end hunger, achieve food security and improved nutrition, and promote sustainable agriculture) and in SDG15 (protect, restore, and promote sustainable use of terrestrial ecosystems, sustainably manage forests, combat desertification, and halt and reverse land degradation and halt biodiversity loss). This role has also been enhanced by institutional bodies such as the European Union. For example, the European Forest Strategy 2020 highlights the importance of the "economic functions of forests and their potential to promote a green economy and to generate and sustain jobs and wages, contributing to rural development". Accordingly, the Resolution of the European Parliament of 28 April 2015 proposed a new EU strategy for forests and requested that the Commission and Member States "create incentives and support new business models, such as production communities, with a view to encouraging small private forest owners to undertake active and sustainable management of their forests". This recognition leads us to infer that the focus of commons management is no longer a matter of efficiency and productivity, but general concern about the landscape and sustainable maintenance. Accordingly, forests are no longer considered a source of timber and other products, but drivers of sustainable growth.

Insofar as economic sustainability represents a growing area of public debate and policy making, a better understanding is needed of the role of commonly owned natural resources. Some countries have faced this challenge by including these resources-and, more properly, the institutions that manage them-under the scope of the Social Economy (SE). The SE comprises a set of organizations whose values focus on solidarity, commitment to the environment, and sustainability [6]. This involves moving from a traditional approach to sustainability from an environmental perspective to another strategy that incorporates economic activity but can also boost the attainment of SDGs [7].

Galicia, a region in Spain, provides a good example on this practice. Law 6/2016 of 4 May, on the SE of Galicia [8], sets out as a major objective promoting the development, consolidation, and improvement of the SE in this region while adapting it to the Galician context $[9,10]$. This objective is made clear when considering the importance of the primary sector in this region. Thus, the second chapter of Law 6/2016 lists those entities pertaining to the SE, including some of the most representative of the primary sector: fishermen's associations, communal forests, and communities of communal forests (cofradias, montes vecinales en mano común, and comunidades de montes vecinales en mano común, respectively). While the fishermen's associations have historical roots in professional medieval institutions, communal forests and communities of communal forests (hereafter, $\mathrm{CFs}$ and CCFs, respectively) are singular institutions collected in the Civil Legal framework of Galicia [11] and are unique in this territory. It should be noted that this does not mean that they are exclusive to this AC, since CFs have a regulatory framework at the state level [12]. What makes this case of greater interest is the inclusion of CFs under the scope of SE, placing these institutions among those capable of generating economic value and contributing to the development of a territory.

In this paper, we focus on these unique forests' common properties that provide new insight into the opportunities of land and forestry to contribute to local development and sustainable economic growth. By doing so, we pursue two major objectives: first, we shed light on a special institution that has been neglected in the literature to date $[13,14]$. Then, we go deeper into this shortage by noting that previous research has primary focused on 
agricultural and livestock activities. Moreover, we highlight how CFs can act as drivers of the rural economy, improving the creation of added value, and, at the same time, demonstrating responsible treatment of endogenous resources. Accordingly, our second objective highlights that, to make this change possible, some inefficiencies must be reversed. Firstly, there is a lack of economic incentives for owners for the rational economic utilization of their property, probably limiting alternative uses. Secondly, this absence of incentives translates into low motivation among local residents to become CCF members. Thirdly, there is a weakness in the management of these organizations, to the extent that in most cases, they are co-administrated by the regional government. Additionally, the absence of a tradition of associationism seriously limits the potential of CCFs to include their interests within the legal mainstream when designing public policies.

Our paper draws on these gaps to suggest how to build a credible picture of the role of CFs in today's socioeconomic environment. We argue that this extends the concept of stakeholders beyond the owners of the common lands and, in particular, involves the inclusion of new stakeholders who are often excluded from the institutions that manage the commons. Moreover, the decisive involvement of public authorities to favor endogenous institutional development is needed since it is essential to the effective achievement of a new management framework $[15,16]$.

In the following sections of the paper, we provide a description of the neighborhood common mountains' context, especially highlighting their relevant features. We then describe their major advantages and disadvantages. After discussing the results of the analysis, we conclude with a set of recommendations to improve their potential to effectively contribute to rural development and cohesion. We finish by outlining the main implications for further investigations.

\section{An Alternative View on Common Forests: The Galician Context}

The concept of "the commons" refers to "a resource shared by a group of people" [17], representing management systems that are used by residents. When referring to land, commons have been traditionally seen as a source of rural development that can contribute to satisfying the needs of the rural population $[18,19]$. Forests managed by communities, as a particular model of land tenure, have raised increasing interest in recent years. However, this research has rarely been addressed by economists, who have conventionally seen common property as a problem rather than an opportunity. Under this approach, it is supposed that common ownership either hinders the efficient management of natural resources or leads to their overexploitation and depletion, a phenomenon commonly known as the "tragedy of the commons" [20]. Accordingly, subsequent research has relied on this caveat from an institutional approach, focusing on the study of the governance mechanisms that guide the decisions of these institutions. In this sense, communitybased forests are governed by the users of the forests. Nevertheless, the set of rules that characterize this governance relate to different property rights systems. These rules vary from private property to government ownership and control, while in other commons, the users basically organize themselves through social norms [21-23]. In short, there are several alternatives "from government to governance" [24]. In this sense, further research is needed to improve knowledge on different kinds of self-governance of forestry resources.

Galicia is a northwestern region of Spain where CFs have existed for centuries, providing the basis for a suitable case study. Galician CFs are a specific form of communal land tenure and a singular legal category in this region. They are defined by the Spanish Government (2012) as "private forests, which with independence of: origin, productive capacity, current utilization, and agrarian vocation, are of the neighbors' communities. In addition, communal forests are exploited in a community regimen, without allocation of quotas among neighbors. Furthermore, these forests are indivisible, inalienable, imprescriptible, and indefeasible goods" [25]. Thus, they conform to a unique type of collective property arrangement based on the traditional ownership rights of a local community. They are privately owned but under a collective system of private ownership without 
special allocation of quotas, which means that the property is a remnant of the Germanic community regime, dating back to the Middle Ages. Regarding this point, Article 3 of Act 13/1989 on the Communal Forests [12] states that "ownership of communal forests is private", while Article 1 states that CFs "belong to neighbor communities in their capacity as social groupings", so the ownership can be only on a group basis.

In turn, each CF is assigned to a neighborhood community (CCF), where each neighbor who represents a house in the community becomes a commoner and will have property rights for the CFs. The resident must manifest his/her willingness to become a member of the CCF. However, commoners have no individual property quota, because CFs are owned by the community that includes all the commoners. Participation in a CCF is open to all new residents, who are linked by a governance system that includes a General Meeting of Commoners-the body of the neighborhood community that owns the CF-and an Executive Board.

Galician CFs have been widely studied from different approaches such as agricultural uses, forest uses and forest fires, and management, e.g., References [14,18,26-30]. However, in this case, there is a notable scarcity of economic analyses that can help us to evaluate the potential of CFs as a driver of sustainable growth as well as a way of improving the wellbeing of rural citizens. As mentioned before, the inclusion of CFs under the scope of SE opens the door for this analysis, insofar as it highlights the importance of CFs in the development and sustainable exploitation of forests.

This approach is of special interest in light of current population trends. Thus, the role of forest resources in environmental outcomes is well known, as well as its significant contribution to rural communities' livelihoods [31]. However, in recent years, rural communities have experienced major social transformations. For example, rural populations have both contracted and aged, while internal mobility has exacerbated these trends, taking working-age people away from their communities. These transformations towards smaller and aging rural populations highlight the need to implement strategies to create labor opportunities in rural settings, which could include forest-related work [32]. Accordingly, new strategies to place forests under effective management are also needed. In this context, Galicia provides a good scenario to test these strategies, due to the challenges that this region faces through the SE framework:

1. Through the Galician Social Economy Law [9,10], Galicia adapts SE to the socioeconomic context of this territory. This region has deeply rooted problems, such as geographical dispersion, depopulation, and abandonment and ageing in rural areas. Thus, the law refers to SE as a way to face these problems, based on the SE's capability to generate quality employment [9]. In other words, the Act mainstreams social and collective entrepreneurship to revitalize rural areas, aiming to achieve economic stability.

2. The inclusion of CCFs as a SE organization gives special importance to their members, namely the commoners. Commoners play a crucial role in guaranteeing the existence of CFs since land is transmitted through successive generations of neighbors who hold the property rights. Accordingly, the community members must maintain their property in the best possible condition for the benefit of future residents.

3. The recognition that forests can create local employment and that their management can cause environmental consequences implies that commoners must continuously engage locals in CFs.

In addition to this economic potential, CCFs have a second interesting advantage regarding their management. At the end of the 20th century, the government instituted reforms aimed at strengthening civil participation in the decision-making processes to reduce inequality. In this context, CCFs were a way to show the capacity of local agents to sustainably manage resources by themselves [21,22]. In essence, they represent a complex community-management-based model [33], capable of involving relevant stakeholders in the decision-making processes, and especially of improving the commitment of individuals to the management of land. This corresponds to a well-known set of advantages 
of community-based resources management, namely that "ownership, usage rights, and management systems are implemented, monitored, and improved by the users themselves, allowing the information on resources and the effectiveness of management to be accumulated among these users" [34]. Based on that accumulated information, management systems can be adapted to cultural environments that include people's beliefs and their views on nature. This collaborative management, a way of sharing authority and responsibility between citizens and the government, has become a crucial element in sustainability [35]. Additionally, local development requires bottom-up strategies involving locals in the catalyzation of the economy [36].

Summarizing, CCFs are called upon to play an important role within a new frame aimed at improving the development of the rural environment, commonly referred to as the new rural paradigm $[37,38]$. This role implies important changes in the process of designing and implementing CCFs' management processes, with simultaneous participation of different actors as a fundamental part of this process. Moreover, it requires the design of strategies aimed at increasing productivity and providing employment opportunities. We discuss these changes in the following sections.

\section{Materials and Methods}

The basis of our research is the analysis of Galician CFs. As has been previously noted, these territories have two distinctive features that are contradictory to some extent. On the one hand, Galicia has one of the largest areas of common lands in Europe. On the other hand, these forests are managed under a unique ownership property system, namely CFs. Thus, in light of this relevance and exclusiveness, we decided to thoroughly identify and describe the Galician CFs as a case study, following previous studies on local commons [17]. Case studies have proven their value as a research methodology to study contemporary phenomena within a real context [39]. In addition, case studies allow us to analyze processes [40]. Thus, this research methodology can be useful both to fully understand the current state of CFs and their management and to investigate how to design strategies to make CFs a driver of sustainable economic growth and employment, especially in rural areas.

Additionally, we obtained and analyzed data from all the CFs in this territory, which allowed us to make conclusions (although not generalizable ones). Regarding this point, it should be noted that there is a remarkable scarcity of official data on CFs as well as alternative sources of information, despite their economic and social relevance. Thus, indirect sources such as the Yearbook of Forestry Statistics of Galicia, published by the Xunta de Galicia, and the Fourth National Forest Inventory issued by the Spanish Ministry of Agriculture, are used to carry out this study. The difficulty of accessing information, together with the large number or CFs, have made it impossible to undertake a field study. Nevertheless, we want to stress the value of this study as the first to analyze these particular organizations and encourage the initiation of other works based on the case studies. At the same time, we call for more information, both public and private, to understand the special case of this type of property.

\section{Results}

\subsection{Galician Communal Forests: Dimensions and Relevance}

Galicia is a green territory, being one of the most important forest areas in Spain. Data from the Fourth National Forest Inventory (2010), undertaken by the Spanish Ministry of Agriculture, Fisheries, and Food, show that Galician forests comprise 2,030,000 hectares, close to $69 \%$ of the territory. This area represents close to $48 \%$ of the Spanish productive forest area. Out of Galicia's total forest area, $97.3 \%$ is private, a surface area of $1,975,190$ hectares, while only $2 \%$ is managed by public administration. In the rest of Spain, the percentage of public forest is considerably higher, at an average of $30 \%$, which is in line with other European countries with a greater allocation of forestry. 
Private forest ownership in Galicia accounts for almost 2 million hectares, representing $66 \%$ of the total territory of the region. While two-thirds of this private ownership belongs to individual properties, the remaining third is collectively owned by local residents through CCFs.

This means that 663,488 hectares are managed by neighborhood communities. These figures suggest the significant economic, social, and environmental value of these organizations. When analyzing Galician CFs, it should be noted that there is a lack of official and reliable information on their total area, which is anywhere from 525,000 to 680,000 hectares according to different sources. In this context, we used data from the Galician government [41] as a single and homogeneous source. According to these data, there were more than 3326 CFs in this region in 2019, with a total surface area of 663,489 hectares.

Figure 1 shows the location of these CFs. As can be noted, they extend throughout the region.
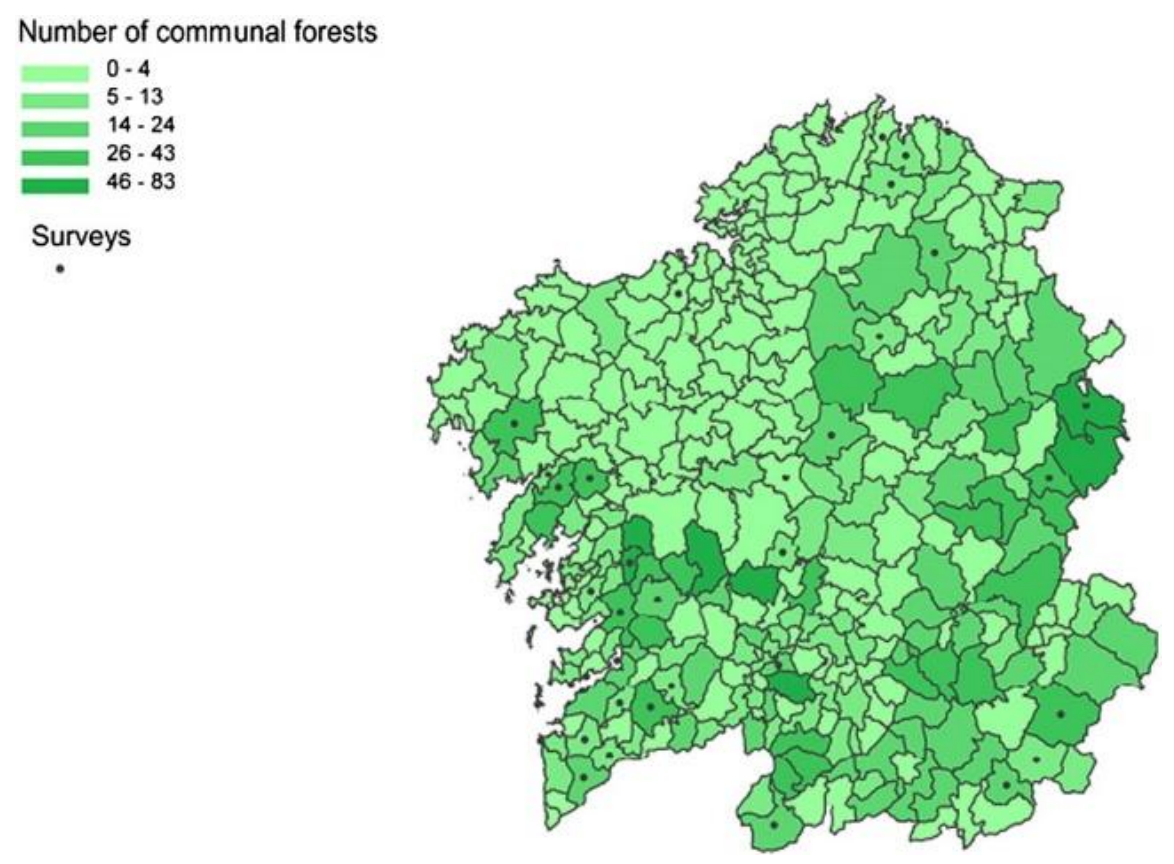

Figure 1. Location of communal forests in Galicia. Source: Fourth National Forest Inventory, Spanish Ministry of Agriculture, Fisheries and Food (2010).

CFs are grouped through forest districts, which are the basic administrative unit for planning and have their own resources. Each district is made up of a group of municipalities, all belonging to the same province. There are 19 districts in Galicia, as shown in Table 1.

As can be seen in the map in Figure 2, the average size of CFs is 219 hectares, ranging from 93.6 hectares in the district Miño-A Arnoia to 429.2 hectares in Verín-Viana-this district being the one with the largest total surface, of almost 93,572 hectares. This average size suggests the potential for extensive exploitation, which ensures their profitability and may guarantee the viability of this economic activity. 
Table 1. Number and area of Communal Forest by district (2019).

\begin{tabular}{cccc}
\hline District & Mounts & Area (Hectares) & Average Area (Hectares) \\
\hline Ferrol & 15 & 4953 & 330 \\
Bergantiños-Mariñas Coruñesas & 23 & 3146 & 137 \\
Santiago-Meseta Interior & 15 & 3919 & 261 \\
Barbanza & 167 & 24,703 & 148 \\
Fisterra & 77 & 11,350 & 147 \\
A Mariña Lucense & 56 & 19,820 & 354 \\
A Fonsagrada-Os Ancares & 282 & 45,933 & 163 \\
Terra de Lemos & 205 & 62,147 & 303 \\
Lugo-Sarria & 287 & 45,923 & 160 \\
Terra Chá & 94 & 28,743 & 306 \\
O Ribeiro-Arenteiro & 263 & 29,137 & 111 \\
Miño-A Arnoia & 328 & 30,069 & 94 \\
Valdeorras-Trives & 207 & 66,190 & 326 \\
Verín-Viana & 218 & 93,572 & 429 \\
A Limia & 248 & 58,467 & 236 \\
Deza-Tabeirós & 131 & 16,180 & 124 \\
O Condado-A Paradanta & 144 & 31,012 & 183 \\
Vigo-Baixo Miño & 201 & 37,738 & 138 \\
Caldas-O Salnés & 365 & 50,487 & 219 \\
Galicia & 3326 & 663,489 & \\
\hline
\end{tabular}

Source: Yearbook of Forestry Statistics of Galicia 2019, Xunta de Galicia (2020) [41].
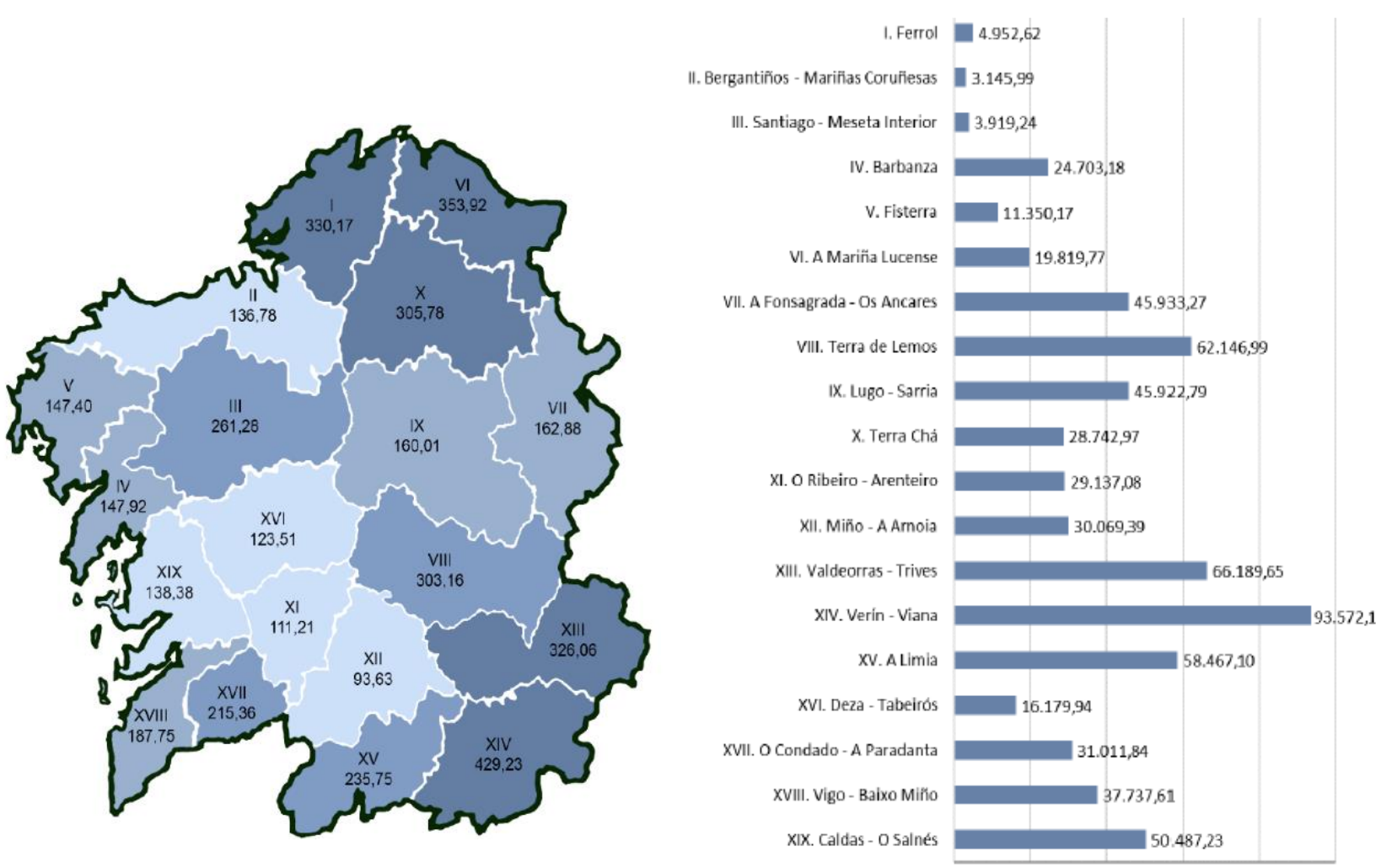

Figure 2. Location of communal forests and average area per district in Galicia (in hectares). Source: Yearbook of Forestry Statistics of Galicia 2019, Xunta de Galicia (2020) [41].

It should be noted that rural property ownership in Galicia has a long tradition of smallholdings (minifundismo). For example, data from the Cadastre and from the Geographical Information System of Agricultural Plots in Galicia [42] reveal that the territory is distributed in more than 11.1 million plots belonging to more than 1.7 million owners. So, 
each private plot has an average area of $0.26-0.28$ hectares, while each owner has 6.45 plots and 1.64 hectares on average. These data contrast strongly not only with those on CFs but those of the leading countries in the forestry sector. This highlights the possibility to better exploit CFs as a way to overcome the problem of distributed property. However, it also reveals that Galicia faces a paradox: while this region has resources with enormous economic potential, a significant part of rural areas is underexploited and undergoing an intense process of economic and demographic deterioration. This suggests that rural areas are not capable of offering an attractive economic option to the population, which must be considered a major problem to be addressed.

\subsection{Communities of Common Forests}

$\mathrm{CFs}$ are structured through communities of common forests (hereafter, CCFs), which in turn are managed by a General Meeting of Commoners and an Executive Board. Participation in these organizations is directly linked to residence in the place that owns the forest. Hence, each individual who moves to live in a place where there is an CF can engage in its management by participating in the decision-making processes, as well as sharing the benefits. In short, CCFs are organizations with an open and inclusive character, whose community members can vary over time. The governing board is responsible for monitoring the CFs and for informing all members of the outcomes and of the annual accounts, while commoners decide through assemblies on the use of the funds (e.g., reinvestment or distribution). Each CCF can therefore decide on how to manage its CF. In practice, there are some communities that have participative management, while others delegate power to the Executive Board.

In Galicia in 2019, there were 118,564 commoners belonging to close to 3000 CCFs. Table 2 shows the interesting relationships between the forestry structure and its management units. First, the number of CCFs per CF is different to 1 in almost all cases. This suggests that some CCFs manage more than one CF. Second, the number of commoners per CCF is highly variable. On average, the number is close to 40. However, in some districts, this figure doubles (Ferrol, for example) or even trebles (Vigo-Baixo Miño). In others, the number is below this average (i.e., A Fonsagrada-Os Ancares, Terra de Lemos, Lugo-Sarria, O Ribeiro-Arenteiro, and Miño-A Arnoia). This could be related to (i) the dispersion of the population in Galicia, where some areas are densely populated while others have lower densities, or (ii) the varying interest of inhabitants in becoming commoners. This second reason is especially important, since it might suggest an absence of information on these structures or simply a lack of commitment of residents to CFs. Finally, the data in Table 2 show some differences in terms of the average area (in hectares) managed by the commoners, which should be linked to the differences in size of the CFs.

A historical overview of CFs offers a further explanation of this different engagement of commoners in the CF management. The Spanish dictatorship (1936-1975) promoted the enclosure of $\mathrm{CF}$ commons, which led to the eviction of residents and contributed to ruralurban migration. Governance of CFs progressively returned to communities from the 1960s to the 1980s, but for a time CFs did not play an important role in the Galician agricultural system and communities did not have agency in forestry activities. Consequently, most residents did not want to take responsibility for CFs. This apparent lack of engagement must be considered a second major problem to face. 
Table 2. Relationships between structures, commoners, and size.

\begin{tabular}{cccc}
\hline District & $\begin{array}{c}\text { Communal Forest/ } \\
\text { Community of } \\
\text { Communal Forest }\end{array}$ & $\begin{array}{c}\text { Commoners/ } \\
\text { Community of } \\
\text { Communal Forest }\end{array}$ & $\begin{array}{c}\text { Area/ } \\
\text { Commoners }\end{array}$ \\
\hline Ferrol & 1.07 & 82.57 & 4.28 \\
Bergantiños-Mariñas Coruñesas & 1.05 & 63.18 & 2.26 \\
Santiago-Meseta Interior & 1.00 & 40.73 & 6.41 \\
Barbanza & 1.10 & 53.88 & 3.02 \\
Fisterra & 1.01 & 43.09 & 3.47 \\
A Mariña Lucense & 1.02 & 57.31 & 6.29 \\
A Fonsagrada-Os Ancares & 1.01 & 6.24 & 26.29 \\
Terra de Lemos & 1.02 & 22.14 & 13.96 \\
Lugo-Sarria & 1.00 & 23.17 & 6.93 \\
Terra Chá & 1.00 & 49.70 & 6.15 \\
O Ribeiro-Arenteiro & 1.09 & 28.62 & 4.22 \\
Miño-A Arnoia & 1.15 & 28.15 & 3.73 \\
Valdeorras-Trives & 1.04 & 19.46 & 17.09 \\
Verín-Viana & 1.08 & 34.26 & 13.59 \\
A Limia & 1.15 & 28.95 & 9.39 \\
Deza-Tabeirós & 1.07 & 21.03 & 6.25 \\
O Condado-A Paradanta & 1.26 & 68.96 & 3.95 \\
Vigo-Baixo Miño & 1.50 & 138.36 & 2.04 \\
Caldas-O Salnés & 1.29 & 78.78 & 2.26 \\
Galicia & 1.11 & 39.63 & 5.60 \\
\hline
\end{tabular}

Source: Yearbook of Forestry Statistics of Galicia 2019, Xunta de Galicia (2020) [41].

\subsection{Communal Forest Results}

As has been previously noted, CCFs are responsible for managing CFs. An analysis of the evolution of average revenue from these organizations between 2015 and 2018 (the last year with available data) shows a continuous decrease of $11.3 \%$ in $\mathrm{CFs}^{\prime}$ average income. As Table 3 shows, this negative result was particularly notable in 2015-2016 (18.3\%). From 2016 to 2018, there was a recovery in income, but not a return to 2015 levels.

Table 3. Average revenue and investment in CCFs (€), 2015-2018.

\begin{tabular}{ccccccccccc}
\hline & \multicolumn{2}{c}{2015} & \multicolumn{2}{c}{$\mathbf{2 0 1 6}$} & \multicolumn{2}{c}{$\mathbf{2 0 1 7}$} & \multicolumn{2}{c}{$\mathbf{2 0 1 8}$} & \multicolumn{2}{c}{$\mathbf{2 0 1 5 - 2 0 1 8}$} \\
\hline & Rev & Invest & Rev & Invest & Rev & Invest & Rev & Invest & Rev & Invest \\
\hline A Coruña & 18,567 & 17,863 & 18,459 & 17,986 & 20,593 & 14,284 & 22,046 & 12,805 & $18.7 \%$ & $-28.3 \%$ \\
Lugo & 32,070 & 16,406 & 32,813 & 24,675 & 29,939 & 12,918 & 28,658 & 15,791 & $-10.6 \%$ & $-3.8 \%$ \\
Ourense & 35,222 & 20,064 & 31,173 & 23,586 & 29,059 & 17,581 & 37,423 & 27,182 & $6.2 \%$ & $35.5 \%$ \\
Pontevedra & 71,822 & 31,038 & 53,103 & 28,031 & 77,562 & 24,810 & 59,432 & 27,010 & $-17.3 \%$ & $-13.0 \%$ \\
Galicia & 45,138 & 22,812 & 36,860 & 24,838 & 44,499 & 18,517 & 40,048 & 22,277 & $-11.3 \%$ & $-2.3 \%$ \\
\hline
\end{tabular}

Source: Yearbook of Forestry Statistics of Galicia 2019, Xunta de Galicia (2020) [41].

The investments made by CCFs, on their part, decreased on average by $2.3 \%$. It is important to note that a significant part of $\mathrm{CFs}^{\prime}$ area was traditionally used for agricultural and livestock purposes, so many of them are now treeless and require significant investment in their forestry and complementary activities. Regarding this point, the law establishes that a minimum of $15 \%$ of the economic benefits obtained must be reinvested in the forests, while the remainder can be divided among the commoners. Regarding this point, sharing among community members is an exception. Additionally, the average income of CFs is about 40 euros per hectare, which contrasts heavily with the average income of 180 euros per hectare for private forests, despite the fact that their average size is significantly lower. This is surprising, taking into account that both the legal framework of CFs and the tax framework are intended to favor these entities. In this regard, their favorable tax treatment is noteworthy. These organizations are compelled to contribute to the Corporate Income 
Tax (Impuesto sobre Sociedades) at a general rate of $25 \%$, but only when they obtain income or do not incur expenditures and investments within their own organization. Additionally, the taxable base of CFs will be reduced for a maximum of four years for the amounts of various reimbursements as follows:

- Investments for the conservation, improvement, protection, access, and services designated for the social use to which the amount is destined.

- Expenditure on the conservation and maintenance of the forest.

- Financing of infrastructure works and public services of social interest.

On another level, CCFs must meet a number of administrative requirements, but not all of them achieve the same degree of compliance. Table 4 shows the percentage of communities that fulfil administrative duties according to the data recorded by the Galician government. Overall, only 1788 (59.8\%) of the 2992 CCFs performed all administrative duties in 2019. As is shown, noncompliance is basically related to a lack of communication regarding reinvestment $(93.5 \%)$.

Table 4. CCFs by administrative status, 2019.

\begin{tabular}{|c|c|c|c|c|}
\hline \multicolumn{5}{|c|}{ Administrative Obligations } \\
\hline \multirow[b]{2}{*}{ District } & \multirow[b]{2}{*}{ Comply } & \multicolumn{2}{|c|}{ Do Not Comply } & \multirow{2}{*}{$\begin{array}{l}\text { Percentage of Communities of } \\
\text { Communal Forests Meeting } \\
\text { Obligations Out of Total }\end{array}$} \\
\hline & & $\begin{array}{l}\text { Lack of Annual } \\
\text { Reporting of } \\
\text { Reinvestments }\end{array}$ & $\underset{* *}{\text { Other Causes }}$ & \\
\hline Ferrol & 10 & 4 & & $71.4 \%$ \\
\hline Bergantiños-Mariñas Coruñesas & 11 & 8 & 3 & $50.0 \%$ \\
\hline Santiago-Meseta Interior & 11 & 4 & & $73.3 \%$ \\
\hline Barbanza & 106 & 36 & 10 & $69.7 \%$ \\
\hline Fisterra & 55 & 18 & 3 & $72.4 \%$ \\
\hline A Mariña Lucense & 38 & 17 & & $69.1 \%$ \\
\hline A Fonsagrada-Os Ancares & 111 & 143 & 26 & $39.6 \%$ \\
\hline Terra de Lemos & 135 & 57 & 9 & $67.2 \%$ \\
\hline Lugo-Sarria & 139 & 134 & 13 & $48.6 \%$ \\
\hline Terra Chá & 65 & 29 & & $69.2 \%$ \\
\hline O Ribeiro-Arenteiro & 106 & 134 & 1 & $44.0 \%$ \\
\hline Miño-A Arnoia & 94 & 190 & 2 & $32.9 \%$ \\
\hline Valdeorras-Trives & 100 & 99 & & $50.3 \%$ \\
\hline Verín-Viana & 142 & 57 & 2 & $70.7 \%$ \\
\hline A Limia & 129 & 85 & 1 & $60.0 \%$ \\
\hline Deza-Tabeirós & 96 & 26 & 1 & $78.1 \%$ \\
\hline O Condado-A Paradanta & 101 & 13 & & $88.6 \%$ \\
\hline Vigo-Baixo Miño & 120 & 14 & & $89.6 \%$ \\
\hline Caldas-O Salnés & 219 & 58 & 7 & $77.1 \%$ \\
\hline Galicia & 1788 & 1126 & 78 & $59.8 \%$ \\
\hline
\end{tabular}

Notes: (*) Lack of annual communication of investments in 2018 (article 125 Law 7/2012, on Galician mountains (**) Other causes: Governing board without renewal, lack of communication of the updated census of community members. Source: Yearbook of Forestry Statistics of Galicia 2019, Xunta de Galicia (2020) [39].

This suggests some concerns that can damage the CFs' potential. Many CCFs not only do not comply with the administrative requirements but lack the basic structure necessary to comply with them and, by extension, to be able to properly manage the CFs. Indeed, $10 \%$ of CCFs do not have statutes or a census of the commoners, half rely on an out-of-date census, and one-third do not have an updated board of directors. It should be noted that the Common Land law provides the option of managing CFs in partnership with the state. Accordingly, while most communities are self-governed, other have passed an agreement or consortium with a public entity to manage their forest area [43]. In this case, the state limits its action to sharing part of the wood revenue with the CCFs. Thus, this formula of 
public management has also been proven to be inefficient, not able to take advantage of the potential of CFs.

In short, the organizational reality of CCFs suggests a problem of deficient professionalized management and a lack of means and instruments to be able to carry out sustainable forest management.

\subsection{Communal Forests as a Stakeholder}

Some communities decided to cooperate via the foundation of organizations such as the Association of Communities of CFs. Law 6/2016, of 4 May, of the SE also includes these entities in the list of implementing organizations. In 2019 (the last year with available data), there were only 34 entities of this type in Galicia. This suggests low interest in these associations, which can limit the potential development of CCFs, which is imperative to defending their intrinsic interests. Additionally, it should be noted that, as organizations included in the SE, they deserve a place on SE councils and decision-making bodies. This absence of an association tradition can, in short, prejudice this representation.

While associations can favor the coordination of activities, this lack of interest should also be considered in light of their role in lobbying. Regarding this point, one of the major objectives of the Galician Social Economy Council is the recognition of the interlocutor role of the SE entities. Interestingly, participation in this council means being able to collaborate on draft regulatory norms affecting the entities of the Galician SE, which is critical for the introduction of a mainstream perspective and for its contribution to the visibility of the sector. Thus, $\mathrm{CCFs}^{\prime}$ associations seem to be crucial to defending $\mathrm{CFs}^{\prime}$ interests and providing the foundation for their development.

\section{Discussion}

The purpose of this paper was to analyze CFs, via the unique model of the Spanish region of Galicia, from an economic point of view. To date, economists seem to have confused common property with undefined ownership or even free access. Furthermore, alternative ownership models such as collective systems of private ownership have gone unnoticed, making it difficult to analyze their profitability potential.

The inclusion of CFs and CCFs under the scope of SE gives a second opportunity to explore their potential as an economic driver, especially in rural areas. Through these structures, it is possible to attain benefits for the area from a social, economic, and environmental perspective. Additionally, CFs can be seen as drivers for employment, thus allowing for the greater engagement of residents in rural areas. Thus, their proper management can favor rural areas in several ways-for example, exploitation of forests, natural resources, and livestock, and production. Simultaneously, CCFs are responsible for the administration and sustainable use of the CFs, with the aim of maintaining and conserving their biodiversity, productivity, and capacity for regeneration, through responsible and sustainable use, from an ecological, social, and cultural point of view.

However, our analysis of CFs reveals that they suffer from inefficiencies that can inhibit their potential as a real driver for territorial development and cohesion. Firstly, while $\mathrm{CFs}^{\prime}$ size suggests opportunities for obtaining benefits from extensive production, data on income and revenue reveal that these organizations are underexploited. Thus, it seems that CCFs are losing opportunities to efficiently produce a multifunctional forest aimed at supporting multiple goods and activities, both timber production and nontimber forest-associated activities. Secondly, in addition to their limited character, the benefits highly on timber production. Consequently, revenues are long-term since any return on investment in forestry takes a long time to materialize. Therefore, this temporary character means that only future commoners will receive the benefits of the investment. The lack of economic incentives translates into low engagement among commoners and even local residents who could become CCF members. Thirdly, there is a weakness in the management of such organizations since they have failed to professionalize the local communities to manage them. Most interestingly, in most cases, $\mathrm{CFs}$ are co-administrated by the regional 
government. As a consequence, there is no real involvement of local residents in the management of community forestry. Finally, the absence of a tradition of associationism inhibits the potential of these organizations to include residents' interests within the legal mainstream and, more specifically, to include specific lines of support-either financial aids or other kinds of support-in the general guidelines to favor the development of SE in Galicia. With regard to this point, it is important to highlight that the financial resources allocated to SE organizations in the Galician budgetary have increased by more than $41 \%$ since 2016, rising to close to $€ 26$ million in 2020. Unfortunately, there are no specific lines of support to CCFs.

These caveats link our study with previous research warning that CFs seem to be anchored to a collective property system without paying attention to their role as sustainability transformation agents, e.g., References [26-28]. We argue that the SE framework favors the transition of CFs from a property system that eventually provides economic outcomes to one aimed at doing so. However, we note that the aforementioned problems reduce the opportunities for Galicia's forests to become a truly efficient and sustainable source of economic activity and employment, as well as to be involved in other important effects such as reversing depopulation and encouraging territorial cohesion.

In these circumstances, some recommendations can be provided to take advantage of the wide potential of these entities. While Figure 3 divides the advice into two groups depending on their position regarding the CFs-inside or outside-it reflects the wellknown scheme of the act of "economic being-in-common" that combines material resources and immaterial ones [41].

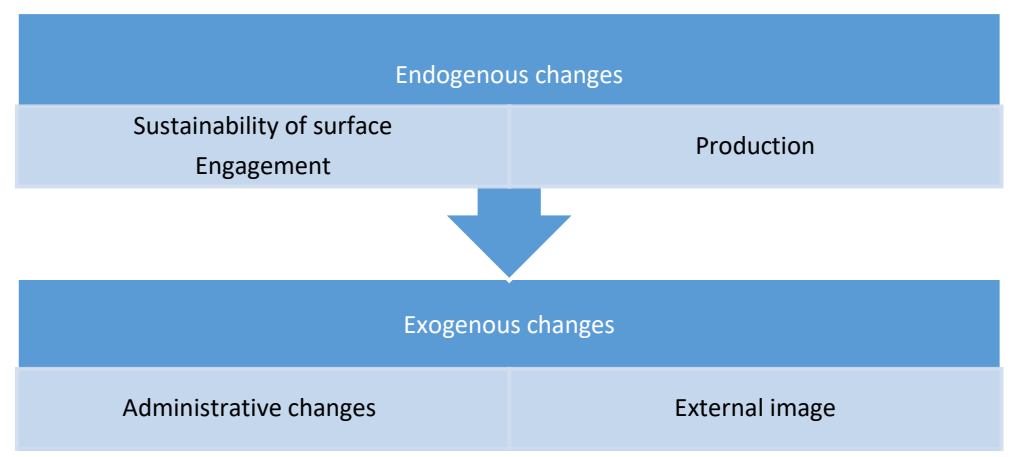

Figure 3. Framework of changes to improve the economic potential of CFs.

\section{- $\quad$ Endogenous Changes}

CCFs manage close to $25 \%$ of Galicia's territory through a collective ownership system that does not allow the area to be divided. Taking into account this indivisibility, the average size of CFs-over 200 hectares—seems to be sufficient to ensure their extensive exploitation, which is imperative in order to achieve profitable production. As mentioned before, CFs belong to a large number of smallholders who must act on a group basis. In these circumstances, the identification and engagement of owners, as well as sustainability, are crucial in order to manage CFs.

The Galician demographic structure seriously threatens these aims. Ageing, rural depopulation, abandonment, and rural-urban migration, represent major problems for the sustainable management of forests [44]. For example, the Galician government estimates that $98.2 \%$ of private forest, representing more than $63 \%$ of the total Galician forest area, is classified as being of doubtful ownership. While this report does not explicitly refer to CFs, it would not be unreasonable to expect that potential future owners will not know their property if they only use it as a second residence and/or for leisure.

Thus, regarding maintenance, it is necessary to continue with the practice of leasing forests. This practice has a two-fold aim: (i) to ensure profitable exploitation, based on the characteristics of certain crops, and (ii) to increase investment, especially in areas suffering 
from abandonment or at risk of it. In this vein, Law 9/2017 of 26 December, on Fiscal and Administrative Measures in Galicia [45], includes a set of measures for when lands are abandoned. Thus, in case of serious abandonment or degradation of CFs, Galicia's government will be able to implement its own forest management by including the CFs in the Bank of Lands of Galicia (Banco de Tierras de Galicia). In turn, this land can be transferred to third parties for its exploitation for a maximum period of 50 years, with a consequent penalty for the former owners.

However, Law 7/2012 of 28 June on Galicia's forest needs further amendments [46]. More properly, it seems imperative to establish a wide range of measures to avoid the risks of abandonment of forest plots, betting on the sustainable use of the forestry. Also, more clarity is needed on the improvement of CF's administrative regime. In the same vein, Decree 32/2016 of 23 March [47], on regulations for the management of Galicia's forests, should be further developed. This decree provides that CCFs must go beyond the extraction of resources and that they are compelled to invest part of their profits in the maintenance and improvement of the forest. Thus, a more explicit development of these provisions might be beneficial to improve the sustainability of investment.

These actions can be useful to preserve the sustainability of the CF's surface, but they cannot guarantee the generational shift by attracting engaged owners, especially younger ones. To attain this objective, the rural environment must be further supported by providing physical and technological infrastructure and ensuring quality public services. Additionally, more diversification of rural workers' sources of income is needed. For example, logging should be considered an important resource but not the only one. In Galicia, many forests have opted for a monoculture of fast-growing species (mainly eucalyptus) that usually generate short-term profitability. However, this does not guarantee continued activity. This results in long-term exploitation without considering further activities. It is clear that this short-sighted strategy does not favor the attainment of other objectives such as sustainability or attracting new residents to sustain the local economy.

Additionally, our analysis revealed that further efforts are needed to effectively engage local residents. To do this, it is imperative to establish a common goal. Assemblies and General Meetings of Commoners seem insufficient to build the necessary commitment to community. However, the consolidation of CFs as a unit for the production and use of resources can aid in creating interdependence among community members, as well as reciprocity to better exploit common resources. In this respect, both direct and indirect actions have to be implemented. Among the former are the improvement of the forests-for example, through the generation of wood or the use of biomass-and the development of activities easily compatible with other uses, such as livestock (fertilizer and animal feed, or silviculture projects), and the production of mushrooms, chestnuts, nuts, resins, and aromatic and medicinal plants. Activities of an indirect nature include the promotion of recreational routes, environmental conservation programs, and environmental education activities. All in all, the main objective is to reinforce rural empowerment by creating income and convincing the rural population that as long as they are involved in the management of the CFs, they can benefit from them.

- $\quad$ Exogenous Changes

The regional administration must do away with its current punitive and/or coercive mechanisms and assume that proactivity and shared responsibility are good practices to ensure responsible management by CCFs. At the same time, support and subsidies should continue to be granted to promote the productive use of Galician forests, since this entails many benefits. Moreover, the catalogue of tax incentives aimed at promoting the exploitation of Galician forests must be greatly improved.

Additionally, Galicia's forestry policy must be the object of more profound improvements in order to avoid the unproductivity of the CFs. Nowadays, forest ownersincluding in those areas that make up CCFs - have to implement a management plan to exploit the forest. To this end, it is essential to continue with measures promoted by the Galician government to ensure compliance with this requirement, such as not allowing 
access to public subsidies, tax benefits, or revenues from cutting wood in the absence of such a management plan. In this same vein, greater efforts are needed to comply with the administrative formalities involved in CCFs, such as the obligation to draw up and publish annual statements-including revenues - or to inform the administrative authority of any changes in the administration or management of these organizations.

CCFs also need to make an effort for the use of resources so as to realize their full potential. Achieving this objective would ensure a better match between supply and demand in forest areas. For this, it is necessary to know both the needs of the community members and the resident population of the area, and to orient production to local potentialities. Therefore, it is imperative to ensure that CCFs have management bodies capable of making decisions on sustainable exploitation to boost the activity of these organizations. Simultaneously, they must be supported by appropriate advice in order to carry out direct forest management. Additionally, they have also been provided with the necessary legal cover so that they can apply professional forest management formulas, which necessarily involve private professional management, with the corresponding monitoring and accountability.

We also note that there is a clear lack of professional management on CCFs that can inhibit the profitable and sustainable exploitation of CFs. To date, common resources are mainly managed through three systems: private property, government ownership and control, and self-governance. In Galicia, we find examples of the three systems when managing CFs. While the degree of failure or success of CCFs varies, most of the selfgoverning and collective private property schemes have failed due to several limitations. Additionally, over $40 \%$ of CCFs have agreements with the regional administration and owner communities. Nevertheless, in this case, the agreement leads to limited productivity, mostly focused on logging.

In these circumstances, more action and more ambition are needed to overcome of the problem of underqualified management. In particular, additional options should be considered, such as private-private and collective-collective collaborations. As for the first, private-private collaboration relies on the capacity and incentive of the CCFs to entrust the management to private initiatives with sufficient investment and knowledge, guaranteeing at the same time financial returns for the CCFs. Regarding the second, merging communities should also be considered. For example, a commonwealth of communities can help to bring together $\mathrm{CFs}$, commoners, and potential owners, thus ensuring the continuity of private collective ownership and management. Additionally, an increased size can favor the consolidation of a professional qualified board of managers capable of changing the paradigm of simple conjoint subjective interest. Finally, an eventual opening of CFs to outsiders for alternative uses should also be considered. This strategy might contribute to communicating the importance and value of $\mathrm{CFs}$ to the general populace.

The starting point of these changes must be commoners' efforts to better manage their common resource as a real unit of production. This means that changes must be implemented through a top-down strategy that highlights the importance of further research on the reasons behind commoners' engagement and the drivers of social commitment, which are rather underexplored aspects of common property. Accordingly, future research should focus on the development of alternative management systems to enhance the participation of stakeholders as a driving force for the socioeconomic and sustainable development of rural areas. This capacity also relies on the opportunity to take advantage of common resources far beyond the extractive function, enabling the generation of greater added value to the economy.

\section{Conclusions}

The persistence over time of Galician CCFs demonstrates that community systems of production can develop self-governing institutions. However, the analysis of these institutions through an economics lens reveals that we have not asked the right questions when studying CFs. Thus, the main question is not whether CCFs have failed due to a 
concrete management but to what extent CCFs might succeed if they implement other institutional instruments. Accordingly, our study addresses this opportunity.

We found that Galician CCFs suffer from different deficiencies, such as a low level of professional management, the low engagement of commoners, no tradition of associationism, and a limited capacity for implementing innovations and/or diversifying activities. The inclusion of CCFs under the scope of SE opens the door to take advantage of new opportunities based on new governing arrangements that are congruent with local conditions. By doing so, more people can recognize CFs' potential as an economic venture capable of providing jobs and income and accept the responsibility to effectively manage the forests. In turn, this can make it possible to contribute to the settlement of the population in rural areas [48].

Summarizing, our study reveals that inefficiencies point to tension among those individuals engaged in forestry ownership but not engaged in production practices. In our view, the problem that underlies this absence of efficiency is that commoners do not have a real sense of the unit of production or organization pertaining to SE. In short, our approach reveals that they are formally included in the SE sector, but not really included. As we hope we have shown through this paper, community-owned property has a high potential of exploitation with social, environmental, and financial possibilities. To realize this opportunity, decisive policies and communication efforts are needed to start the journey.

Author Contributions: Conceptualization, A.V.G. and M.B.; methodology, A.V.G., M.Á.V.T. and M.B.; formal analysis, A.V.G., M.Á.V.T. and M.B.; writing-original draft preparation, A.V.G.; writingreview and editing, A.V.G., M.Á.V.T. and M.B.; visualization, A.V.G., M.Á.V.T. and M.B.; supervision, A.V.G. All authors have read and agreed to the published version of the manuscript.

Funding: This research received no external funding.

Data Availability Statement: The data presented in this study are available on request from the corresponding author.

Conflicts of Interest: The authors declare no conflict of interest.

\section{References}

1. Brown, K.M. New challenges for old commons: The role of historical common land in contemporary rural spaces. Scott. Geogr. J. 2006, 122, 109-129. [CrossRef]

2. Hess, C.; Ostrom, E. Understanding Knowledge as Commons; The MIT Press: Cambridge, MA, USA, 2007.

3. Orlandi, L.B.; De Martino, E.; Rossignoli, C.; Bonomi, S. Strategic value of agricultural business networks in sustaining common goods. Sustainability 2019, 11, 5986. [CrossRef]

4. United Nations General Assembly. Transforming Our World: The 2030 Agenda for Sustainable Development; Division for Sustainable Development Goals: New York, NY, USA, 2015. Available online: https://sustainabledevelopment.un.org/post2015/ transformingourworld/publication (accessed on 20 October 2020).

5. Bastida, M.; Vaquero, A.; Cancelo, M.; Olveira Blanco, A. Fostering the sustainable development goals from an ecosystem conducive to the SE: The Galician's case. Sustainability 2020, 12, 500. [CrossRef]

6. Solórzano, M.; Guzmán, C.; Savall, T.; Villajos, E. Identidad de la empresa social en España: Análisis desde cuatro realidades socioeconómicas. CIRIEC España Rev. Econ. Pública Soc. Coop. 2018, 92, 155-182. [CrossRef]

7. Vatananan, R.; Schaller, A.; Shannon, R. A Bibliometric review of the knowledge base for innovation in sustainable devel-opment. Sustainability 2019, 11, 5783-5805. [CrossRef]

8. The Spanish Government. Official State Gazette (BOE) 18/05/2016. Law 6/2016, of 4th May on the Social Economy in Galicia. 2016. Available online: https://www.boe.es/buscar/act.php?id=BOE-A-2016-5943 (accessed on 21 October 2020).

9. Bastida, M.; Vaquero, A.; Cancelo Márquez, M.T. La ley de economía social de Galicia. In La Economía Social en la Comunidad Valenciana: Regulación y Políticas Públicas; Fajardo, G., Chavez, R., Eds.; CIRIEC-España: Valencia, Spain, 2019 ; pp. 43-52.

10. Bastida, M.; Vaquero, A.; Cancelo, M.T. La contribución de la ley de economía social al desarrollo territorial y la mejora del empleo. Revesco Rev. Estud. Coop. 2020, 134, 1-20.

11. The Spanish Government. Official State Gazette (BOE) 29/06/2006. Law 2/2006, of 14th June on Civil Law in Galicia. 2006. Available online: https:/ / www.boe.es/buscar / act.php?id=BOE-A-2006-14563 (accessed on 23 October 2020).

12. The Spanish Government. Official State Gazette (BOE) 09/02/1990. Law 13/1989, of 10th October on Communal Forests. 1990. Available online: https:/ / www.boe.es/buscar/doc.php?id=BOE-A-1990-3358 (accessed on 23 October 2020). 
13. Bastida, M.; Vaquero, A. Las comunidades y mancomunidades de montes mano común. In Libro Blanco de la Economía Social en Galicia 2019; Cancelo, M.T., Botana, M.J., Eds.; Universidad de Santiago de Compostela—Centro de Estudios Cooperativos: Santiago de Compostela, Galicia, 2019.

14. Bastida, M.; Vaquero, A. Las comunidades y mancomunidades de montes mano común. In Libro Blanco de la Economía Social en Galicia 2020; Cancelo, M.T., Botana, M.J., Eds.; Universidad de Santiago de Compostela-Centro de Estudios Cooperativos: Santiago de Compostela, Galicia, 2020.

15. Dobson, A. Environmental citizenship: Towards sustainable development. Sustain. Dev. 2007, 15, 276-285. [CrossRef]

16. Dobson, A.; Bell, D. (Eds.) Environmental Citizenship; The MIT Press: Cambridge, MA, USA, 2005.

17. Ono, C.; Ishikawa, M. Pastoralists' herding strategies and camp selection in the local commons-A case study of pastoral societies in Mongolia. Land 2020, 9, 496. [CrossRef]

18. Gómez, I.; Álvarez, P.; Marey, M.F. Conflicts as enhancers or barriers to the management of privately owned common land: A method to analyze the role of conflicts on a regional basis. For. Policy Econ. 2009, 11, 617-627.

19. Elands, B.H.; O'Leary, T.N.; Boerwinkel, H.W.; Wiersum, K.F. Forests as a mirror of rural conditions: Local views on the role of forests across Europe. For. Policy Econ. 2004, 6, 469-482. [CrossRef]

20. Hardin, G. The tragedy of the commons. Science 1968, 162, 1243-1248. [PubMed]

21. Ostrom, E. Governing the Commons: The Evolution of Institutions for Collective Action; Cambridge University Press: Cambridge, UK, 1990.

22. Ostrom, E. Understanding Institutional Diversity; Princeton University Press: Princeton, NJ, USA, 2005.

23. Ostrom, E. Beyond markets and states: Polycentric governance of complex economic systems. Am. Econ. Rev. 2010, 100, 641-672. [CrossRef]

24. Hackett, R. From government to governance? Forest certification and crisis displacement in Ontario, Canada. J. Rural Stud. 2013, 30, 120-129. [CrossRef]

25. The Spanish Government. Official State Gazette (BOE) 08/09/2012. Law 7/2012, of 2nd June on Galician Forests. 2012. Available online: https:/ / www.boe.es/boe/dias/2012/09/08/pdfs/BOE-A-2012-11414.pdf (accessed on 23 October 2020).

26. Marey, M.F.; Rodríguez, V. Factors determining forest management by farmers in northwest Spain: Application of discriminant analysis. For. Policy Econ. 2011, 13, 318-327. [CrossRef]

27. Soliño, M.; Álvarez-Farizo, B.; Campos, P. The influence of home-site factors on residents' willingness to pay: An application for power generation from scrubland in Galicia, Spain. Energy Policy 2009, 37, 4055-4065. [CrossRef]

28. Bisquert, M.; Caselles, E.; Sánchez, J.M.; Caselles, V. Application of artificial neural networks and logistic regression to the prediction of forest fire danger in Galicia using MODIS data. Int. J. Wildland Fire 2012, 21, 1025-1029. [CrossRef]

29. Caballero, G. Community-based forest management institutions in the Galician communal forests: A new institutional ap-proach. For. Policy Econ. 2015, 50, 347-356. [CrossRef]

30. Alló, M.; Loureiro, M.L. Evaluating the fulfillment of the principles of collective action in practice: A case study from Galicia (NW Spain). For. Policy Econ. 2016, 73, 1-9. [CrossRef]

31. Shackleton, C.M.; Shackleton, S.E.; Buiten, E.; Bird, N. The importance of dry woodlands and forests in rural livelihoods and poverty alleviation in South Africa. For. Policy Econ. 2007, 9, 558-577. [CrossRef]

32. Robson, J.P.; Wilson, S.; Sanchez, C.M.; Bhatt, A. Youth and the future of community forestry. Land 2020, 9, 406. [CrossRef]

33. Cox, M.; Arnold, G.; Tomás, S.V. A Review of design principles for community-based natural resource management. Ecol. Soc. 2010, 15, 38. [CrossRef]

34. Ostrom, E.; Schlager, E. The formation of property rights. In Rights to Nature: Ecological, Economic, Cultural, and Political Principles of Institutions for the Environment; Hanna, S.S., Folke, C., Mäler, K.-G., Eds.; Island Press: Washington, DC, USA, 1996 ; pp. 127-156.

35. Kosamu, I.B. Conditions for sustainability of small-scale fisheries in developing countries. Fish. Res. 2015, 161, 365-373. [CrossRef]

36. Coll Serrano, V.; Cuñat Gimenez, R. Contribuyen las cooperativas de reciente creación al desarrollo local? Una visión desde los principios cooperativistas. Rev. Venez. Econ. Soc. 2007, 7, 8-29.

37. Kitchen, L.; Marsden, T. Creating sustainable rural development through stimulating the echo-economy: Beyond the echoeconomic paradox? Sociol. Rural. 2009, 49, 273-294. [CrossRef]

38. Woods, M. Rural; Routledge Taylor \& Francis Group: London, UK, 2011.

39. Yin, R.K. Case Study Research: Design and Methods; Sage Publications: Thousand Oaks, CA, USA, 1994.

40. George, A.L.; Bennett, A. Case Studies and Theory Development in the Social Sciences; The MIT Press: Cambridge, MA, USA, 2005.

41. The Galician Government (Xunta de Galicia). Yearbook of Forestry Statistics of Galicia 2019; Xunta de Galicia: Santiago de Compostela, Galicia, 2020.

42. Galician Institute of Statistics (IGE). Information System of Rustic Plots. Available online: https://www.ige.eu/igebdt/selector. jsp?COD $=603 \&$ paxina $=001 \& c=0101001002$ (accessed on 27 October 2020).

43. Instituto de Desarrollo Económico de Galicia; IDEGA; Communal forest Research Group. La política forestal gallega en los montes vecinales en mano común. Ambienta 2013, 104, 114-125.

44. Gibson-Graham, J.K. A Postcapitalist Politics; University of Minnesota Press: Minneapolis, MN, USA, 2006.

45. The Galician Government. Official Gazette of Galicia (DOG) 27/12/2017. Law 9/2017 of 26 December, on Fiscal and Administrative Measures in Galicia. Available online: https://www.boe.es/diario_boe/txt.php?id=BOE-A-2018-1753 (accessed on 23 October 2020). 
46. The Galician Government. Official Gazette of Galicia (DOG) 12/08/2012. Law 7/2012, of 28 June of mountains of Galicia. Available online: https://www.xunta.gal/dog/Publicados/2012/20120723/AnuncioC3B0-050712-0001_gl.html (accessed on 27 October 2020).

47. The Galician Government. Official Gazette of Galicia (DOG) 04/04/2016. Decree 32/2016, of 23rd March, Amending Decree 52/2014, of 16th April, on General Instructions for Planning and Management of Galicia's Forestry. 2016. Available online: https://www.xunta.gal/dog/Publicados/2016/20160404/AnuncioG0426-290316-0002_es.html (accessed on 27 October 2020).

48. Vaquero, A.; Losa, V. Actuaciones desde la administración pública para evitar la despoblación del medio rural: Qué se puede hacer desde los ayuntamientos y diputaciones? Revista Gallega de Economía 2020, 29, 1-14. [CrossRef] 